\title{
PRESENCE OF PESTICIDE RESIDUES IN IMPORTED FROZEN FISH
}

\author{
${ }^{1}$ Yasser M. Al-Ashmawy; ${ }^{2}$ Nader Y. Moustafa and ${ }^{2}$ Ibrahim I. Al-Hawary \\ ${ }^{1}$ B.V.Sc, Fac. of Vet. Med., Kafrelsheikh Univ. \\ ${ }^{2}$ Food Control Dep. Fac. of Vet. Med., Kafrelsheikh Univ, Egypt.
}

\begin{abstract}
45 random samples of imported frozen fish were collected from $\mathrm{Al}$ Gharbiah markets, Egypt. The collected samples were represented by Synodus Saurus (Saurus), Trachurus trachurus (Atlantic-Horse Mackerel) and Scomber scombrus (Mackerel) fish, (15 of each). The collected samples (fish flesh) were examined for determination of pesticide residues (aldrin and malathion) on the basis of wet weight (ppb) by High Performance Liquid Chromatography (HPLC) apparatus. The obtained results revealed that the mean concentrations of aldrin in the examined samples of imported frozen Saurus, AtlanticHorse Mackerel and Mackerel fish were $59.75 \pm 2.53$ ppb, $124.1 \pm 4.92 \mathrm{ppb}$ and $150.86 \pm 6.38 \mathrm{ppb}$, respectively. However The mean concentrations of malathion in the examined samples of imported frozen Saurus, Atlantic-Horse Mackerel and Mackerel fish were $110.80 \pm 4.47 \mathrm{ppb}, 181.80 \pm 5.22 \mathrm{ppb}$ and $243.60 \pm 8.95 \mathrm{ppb}$, respectively. Comparing the results to the maximum permissible limits stated by the Egyptian Organization of Standardization "EOS" (2005), found that the examined frozen mackerel fish contained the highest residual concentrations of pesticides (aldrin and malathion) followed by Atlantic-Horse Mackerel and Saurus fish.
\end{abstract}




\section{INTRODUCTION}

Fish is a traditional and important food in the Egyptian's diet. The quantity of imported fish was increased to fulfill the demand of animal protein. There are expectations of increased fish demand for consumption not only due to population growth, but also due to increasing price gap between fish and alternatives animal protein such as meat. (Hassan et al., 2011).

Pesticides can be defined as any substance or mixture of substances intended for prevention, destroying or controlling any pest act as vectors of human or animal diseases and unwanted species of plants (Goldman et al., 1990). The problem of pesticide residues in food has been addressed at international level through several committee sponsored by some United Nations organizations (FAO/WHO). Contamination of food of animal origin by organochlorine and organophosphorus compounds and their metabolites has been reported in various countries. Generally, most of pesticides are toxic to all forms of life and vary widely in their degree of possible hazards (Neumann, 1988).

Aldrin and dieldrin are organochlorine insecticides with similar chemical structures. Aldrin rapidly changed to dieldrin in plants and animals, dieldrin is stored in the fat and leaves the body very slowly, aldrin and dieldrin found in food like fish or shellfish from contaminated lakes or streams, or contaminated root crops, dairy products, or meat (ATSDR, 2002).

Malathion is a broad spectrum, non-systemic Organophosphorus insecticide that is highly toxic to fish and aquatic invertebrates, but does not appear to be toxic to plants. Some residential and agricultural uses have rather high application rates and resulting exposure (Jeannette and Jennifer, 2004). 
Therefore, this study was planned to:

Detection of pesticide pollutants of (Aldrin and Malathion) in imported frozen fish from different countries.

\section{MATERIALS AND METHODS}

\section{1- Collection of samples:}

A total of 45 random samples of imported frozen fish were collected from Al-Gharbiah markets, Egypt, the collected samples were represented by Saurus, Atlantic-Horse Mackerel and Mackerel fish (15 of each) The collected samples (fish flesh) were examined for determination of pesticide residues (aldrin and malathion) on the basis of wet weight (ppb).

\section{2-Determination of pesticides (aldrin and malathion):}

2-1- Extraction and purification according to (Bonsir et al., 2007).

2-2- Partitioning according to $(A O A C, 1990)$.

2-3- Clean-up according to (Serrano et al., 2008).

2-4- Preparation of stock standards.

2-5- Preparation of chromatographic working standards.

2-6- Preparation of the extracted sample.

\section{2-7- Chromatography:}

The prepared samples were examined for determination of pesticide residues (aldrin and malathion) on the basis of wet weight (ppb) by High Performance Liquid Chromatography (HPLC) apparatus. 


\section{RESULTS}

Table (1): Statistical analytical results of aldrin concentrations in the examined samples of imported frozen fish $(n=15)$.

\begin{tabular}{|c|c|c|c|c|c|}
\hline \multirow{2}{*}{$\begin{array}{c}\text { Types of } \\
\text { imported fish }\end{array}$} & \multirow{2}{*}{$\begin{array}{l}\text { NO. of positive } \\
\text { samples }\end{array}$} & \multirow{2}{*}{$\begin{array}{c}\text { Percentage of } \\
\text { positive samples }\end{array}$} & \multicolumn{3}{|c|}{ Concentrations (PPb) } \\
\hline & & & Min & Max & Mean \pm S.E \\
\hline Saurus & 2 & 13.33 & 23.70 & 995.80 & $59.75 \pm 2.53$ \\
\hline $\begin{array}{c}\text { Atlantic-Horse } \\
\text { Mackerel }\end{array}$ & 2 & 13.33 & 41.30 & 206.90 & $124.10 \pm 4.92$ \\
\hline Mackerel & 5 & 33.33 & 58.70 & 263.10 & $150.86 \pm 6.38$ \\
\hline
\end{tabular}

Table (2): Acceptability of the examined imported frozen fish samples based on their concentrations of aldrin.

\begin{tabular}{||c||c|c|c||c||}
\hline Types of imported fish & NO. of samples & $\begin{array}{c}\text { NO. of samples } \\
\text { above MRL }\end{array}$ & $\begin{array}{c}\text { \% of samples above } \\
\text { MRL (Unaccepted) }\end{array}$ & MRL (PPb)* \\
\hline \hline Saurus & 15 & 0 & 0 & 200 \\
\hline $\begin{array}{c}\text { Atlantic-Horse } \\
\text { Mackerel }\end{array}$ & 15 & 1 & 6.67 & 200 \\
\hline Mackerel & 15 & 2 & 13.33 & 200 \\
\hline
\end{tabular}

* Egyptian Organization of Standardization "EOS" (2005)

Table (3): Statistical analytical results of Malathion concentrations in the examined samples of imported frozen fish $(n=15)$.

\begin{tabular}{|c|c|c|c|c|c|}
\hline \multirow{2}{*}{$\begin{array}{c}\text { Types of } \\
\text { imported fish }\end{array}$} & \multirow{2}{*}{$\begin{array}{c}\text { NO. of positive } \\
\text { samples }\end{array}$} & \multirow{2}{*}{$\begin{array}{c}\text { Percentage of } \\
\text { positive samples }\end{array}$} & \multicolumn{3}{|c|}{ Concentrations $(\mathbf{P P b})$} \\
\hline & & & Min & Max & Mean \pm S.E \\
\hline Saurus & 2 & 13.33 & 48.50 & 173.10 & $110.80 \pm 4.47$ \\
\hline $\begin{array}{c}\text { Atlantic-Horse } \\
\text { Mackerel }\end{array}$ & 3 & 20.00 & 64.10 & 329.60 & $181.80 \pm 5.22$ \\
\hline Mackerel & 5 & 33.33 & 92.50 & 356.40 & $243.60 \pm 8.95$ \\
\hline
\end{tabular}

Table (4): Acceptability of the examined imported frozen fish samples based on their concentrations of malathion.

\begin{tabular}{|c|c|c|c|c|}
\hline Types of imported fish & NO. of samples & $\begin{array}{c}\text { NO. of samples } \\
\text { above MRL }\end{array}$ & $\begin{array}{l}\text { \% of samples above } \\
\text { MRL (Unaccepted) }\end{array}$ & MRL $(\mathbf{P P b})^{*}$ \\
\hline Saurus & 15 & 0 & 0 & 300 \\
\hline $\begin{array}{c}\text { Atlantic-Horse } \\
\text { Mackerel }\end{array}$ & 15 & 1 & 6.67 & 300 \\
\hline Mackerel & 15 & 3 & 20.00 & 300 \\
\hline
\end{tabular}

* Egyptian Organization of Standardization "EOS" (2005)

$\overline{\text { Kafrelsheikh Vet. Med. J. Vol. } 10 \text { No. } 2 \text { (2012) }}$ 


\section{DISCUTION}

It is evident from the results recorded in table (1) that the concentration of aldrin in the examined samples of imported frozen fish ranged from 23.70 to $95.80 \mathrm{ppb}$ with a mean of $59.75 \pm 2.53 \mathrm{ppb}, 41.30$ to $206.90 \mathrm{ppb}$ with a mean of $124.1 \pm 4.92 \mathrm{ppb}$ and 58.70 to $263.10 \mathrm{ppb}$ with a mean of $150.86 \pm 6.38 \mathrm{ppb}$ for imported frozen Saurus, AtlanticHorse Mackerel and Mackerel fish, respectively.The above mentioned concentrations nearly similar to those obtained by Henry et al. (1998) and Verma et al. (2006), while lower concentrations were recorded by Shailaja and Singhal (1994) and Shailaja and Nair (1997).

According to the permissible limits of aldrin stipulated by (EOS, 2005), results in table (2) showed that $6.67 \%$ and $13.33 \%$ of examined imported frozen Atlantic-Horse Mackerel and Mackerel fish, respectively, were unfit for human consumption where they exceed this permissible limits.

Concerning to the results recorded in table (3) the concentration of malathion in the examined samples of imported frozen fish ranged from 48.50 to $173.10 \mathrm{ppb}$ with a mean of $110.80 \pm 4.47 \mathrm{ppb}, 64.10$ to 329.60 ppb with a mean of $181.80 \pm 5.22 \mathrm{ppb}$ and 92.50 to $356.40 \mathrm{ppb}$ with a mean of $243.60 \pm 8.95 \mathrm{ppb}$ for imported frozen Saurus, Atlantic-Horse Mackerel and Mackerel fish, respectively.

Many authors referred to the presence of oganophosphorus pesticides in fish, water and sediments such as Hanazato (1991) and Soumis et al. (2003). Malathion contamination has a bad effect on the aquatic communities despite the fact that it is globally applied and can be legally applied directly over water (Kiely, 2004). 
Regarding to the permissible limits of aldrin stipulated by (EOS ,2005), results in table (4) decleared that $6.67 \%$ and $20 \%$ of the examined imported frozen Atlantic-Horse Mackerel and Mackerel fish were unfit for human consumption, respectively, where they exceed this permissible limits.

The obtained results in the present study indicated that the examined imported frozen Mackerel fish contained the highest residual levels of pesticides (aldrin and malathion) followed by Atlantic-Horse Mackerel and Saurus fish.

\section{REFERNCES}

- ATSDR “Agency for Toxic Substances and Disease Registry" (2002): Toxicological profile for aldrin and dieldrin. Atlanta, GA: U.S. Department of Health and Human Services, Public Health Service.

- AOAC “Association Official of Analytical Chemists" (1990): Official Methods of Association Official of Analytical Chemists for determination of pesticide residues. 12th Ed., pp.518, Publishing Co., Washington D.C., USA.

- Bonsir, J.; Puntaric, D.; Smit, Z.; Klaric, M.; Grgic, M.; and Kosanovic, L.M. (2007): Organochlorine pesticides in freshwater fish from the Zagreab area, Arh. Hig. Rada. Toksikol 58:187-193.

- E.O.S. "Egyptian Organization for Standardization and Quality Control" (2005): Maximum residual limits for Malathion in food, No.2222/05 and Maximum residual limits for Aldrin in food, No 2078/92. 
- Goldman, L.R.; Smith, D.F.; Neutra, R.R.; Saunders, L.D.; Pond, E.M.; Stratien, X.; Waller, K.; Laefcsen, R. J. and Kiger, K.W. (1990): Pesticide food poisoning from contaminated water melons in California, 1985. Arch. Environ. Health. 45: 229.

- Hanazato, T. (1991): Effects of long- and short-term exposure to carbaryl on surrival, growth and reproduction of Daphnia magnia. Environ. Pollut. 74, 139-148.

- Hassan A. Ahlam; Afaf Z. Othman and Nayera Y. Sulaiman (2011): Economic Study of Some Factors Impact on the Fish Consumption in Egypt, original articles of applied sciences research, 7(12): 18341839, ISSN 1819-544X.

- Henry, K.S.; Kannan, K.; Nagy, B.W., Kevern, N.R.; Zabik, M.J. and Giesy, J.P. (1998): Concentrations and hazard assessment of organochlorine contaminants in smallmouth bass from a remote lake in the upper peninsula of Michigan. Arch. Environ. Contam. 34, 81-86.

- Jeannette, M. and Jennifer, L. (2004): Malathion Analysis of Risks to Endangered and Threatened Salmon and Steelhead. Environmental Field Branch Office of Pesticide Programs USA. http:// www.epa.gov/ oppsrrd1/op /Malathion .htm.

- Kiely, T. (2004): Pesticide industry sales and usage: 2000 and 2001 market estimates. United States Environmental Protection Agency, Washington, DC. EPA-733-R-04-001 www.epa.gov/pesticides. 
- Neumann, G.B. (1988): The occurrence and variation of organochlorine pesticide residues detected in Australian live stock at slaughter. Acta Veternaria Scandinavica 84:299.

- Serrano, R.; Barreda, M. and Blanes, M.A. (2008): Investigating the presence of organochlorine pesticides and polychlorinated biphenyls in wild and farmed gilthead sea bream (Sparus aurata) from the Western Mediterranean sea. Marine Pollution Bulletin 56 (5): 963-972.

- Shailaja, M.S. and Singhal, S.Y.S. (1994): Organochlorine pesticide compounds in organisms from the Bay of Bengal. Estuarine Coastal and Shelf Science. 39: 219-226.

- Shailaja, M.S. and Nair Maheshwari (1997): Seasonal differences in organochlorine pesticide concentrations of zooplankton and fish in the Arabian Sea. Marine Environmental Research 44(3): 263-274.

- Soumis, N.; Marc, L.; Delaine, S.; Diane, C. A.; Dalie, G.; Silmara, M. and Pierre, P. (2003): Presence of organophosphate insecticides in fish of the Amazon River, Acta Amazonia, jou 33(2): 325-338.

- Verma, D.; Sharma, A. and Sharma, M. (2006): Originalarbeiten Residues of Chlorinated Hydrocarbons in Fishes: A GLC Analysis. Acta hydrochimica et hydrobiologica. 19 (4): 431 - 433. 
تو اجد متبقيات المبيدات الحشرية فى الأسماك المجمدة المستوردة 1 ياسر محفوظ العشماوي، 2 أ.د ـ نادر يحيى مصطفى، 2 أ.د/ إبراهيم إبراهيم الهواري

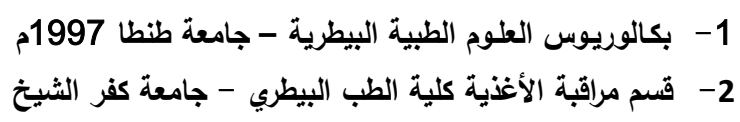

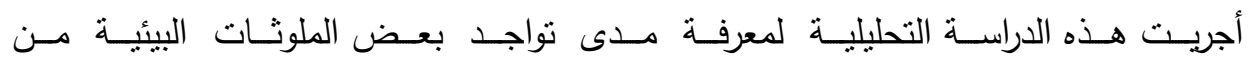

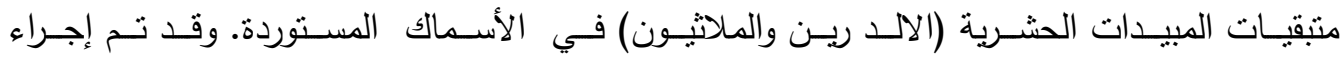

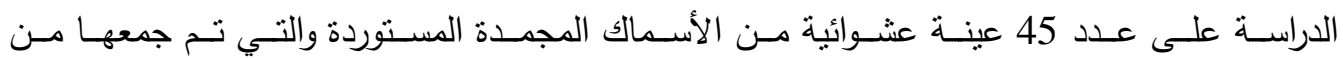

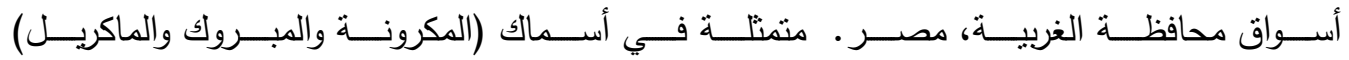
وذللك بواقع 15 عينة من كل نوع من هذه الأسماك.

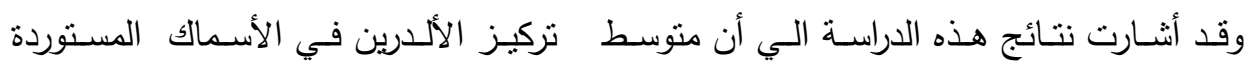

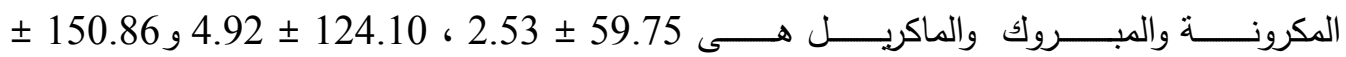
6.38 جزء في البليون ,على التوالي.

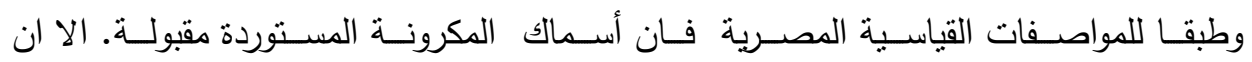

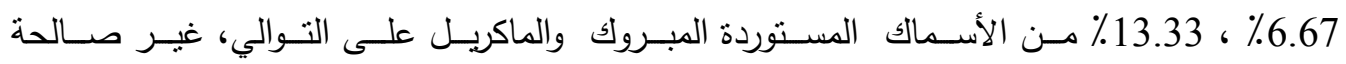
وتتجاوز الحد الأقصى المسموح به للألدرين.

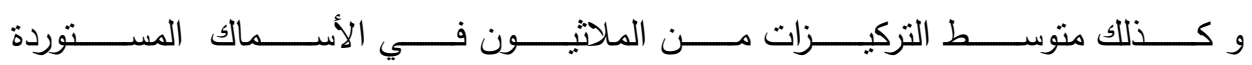

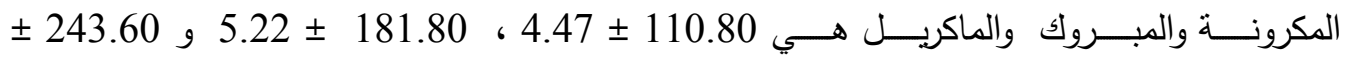
8.95 جزء في البليون, على التوالي.

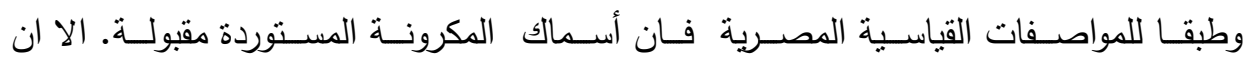

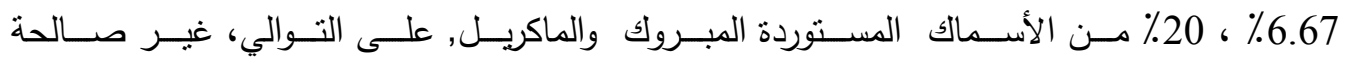
وتتجاوز الحد الأقصى المسموح بة للملاثيون.

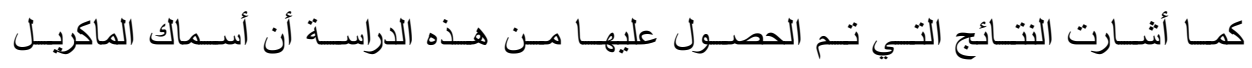

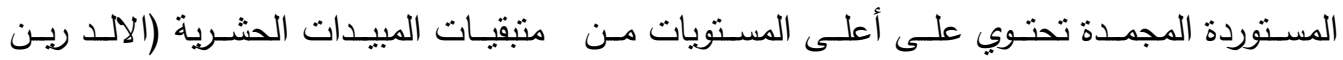

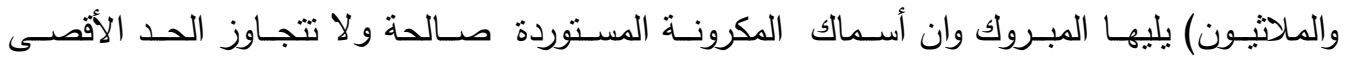

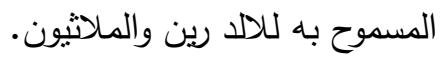

